It is emphasized that formation of a professional competence of future junior medical specialists depends to a large extent on the quality of educational and methodological achievements and the effectiveness of the educational process in the educational environment of the medical college, which is aimed at conscious consideration of the possibilities of subjects of general, natural and scientific sciences and cycles of training future physicians.

Key words professional orientation of teaching physics, integration of fundamental and professional training, medical college.

Удк 378.016:[80+33+002.1]

Марія Якубовська

Українська академія друкарства

ORCID ID 0000-0002-7774-955X

DOI 10.24139/2312-5993/2019.07/336-344

\title{
ДУХОВНО-ЕКЗИСТЕНЦІЙНИЙ АРХЕТИП КОМУНІКАТИВНОГО ДІАЛОГУ ПИСЬМЕННИКА АНАТОЛІЯ КРИМА ЯК ЗАСІБ ФОРМУВАННЯ КУЛЬТУРОЛОГІЧНОЇ КОМПЕТЕНТНОСТІ СУЧАСНОГО СТУДЕНТА
}

На прикладі дослідження творчості видатного сучасного письменника Анатолія Крима розглядаються проблеми формування культурологічної компетентності сучасного студента як основи творення нової культурологічної парадигми сучасності, що є важливим чинником формування гуманітарної безпеки суспільства. Методологія дослідження полягає в застосуванні компаративного, історико-логічного, синергетичного методів. Досліджується системне творення культурологічної моделі художнього тексту як цілісної функціональної єдності сутності художнього слова й навколишнього світу, розширення уявлень про синенергетичну взаємодію між формуванням світогляду людини та гармонійним розвитком соціуму.

Ключові слова: культурологічна компетентність, культурологічний світогляд, дискурс, синергія слова, філософсько-психологічний код слова, мистеитво спілкування, культурологічне середовище, архетип твору.

Постановка проблеми. У час народження нових моделей духовного існування людства - нашого ірраціонального переходу від однієї епохи до іншої, зародження основ квантового мислення - надзвичайно важливим $є$ усвідомлення архетипної моделі світу сучасної інноваційної культури, що формується в умовах великого напруження креативної фахової моделі духовно-екзистенційного мислення, яке є основою діалогу культур.

Аналіз актуальних досліджень. У сучасних умовах існує низка досліджень даної наукової проблеми, серед яких виділяємо такі напрями: аксіологічний підхід (В. Андрєєв, С. Анісімов, В. Андрущенко, О. Асмолов, Г. Бал, І. Бех, Т. Бутківська, О. Вишневський, Б. Грушунський, В. Грехнєва, В. Кремінь, Н. Ничкало, Ю. Пелех, В. Сластьонін, Е. Соколов та ін.); особистісний напрям, який представлють К. Абульханова-Славська, Б. Ананьєв, О. Асмолов, П. Блонський, Л. Божович, Й. Боришевський, Л. Виготський, В. Давидов, У. Джеймс, П. Жане, Г. Костюк, М. Ланге, 
О. Леонтьєв, Ф. Лерш, А. Маслоу, В. Мерлін, В. Моляко, Г. Олпорт, П. Пелех, К. Платонов, К. Роджерс, С. Рубінштейн та ін. Системне використання синергетичного методу у формуванні духовно-екзистенційної моделі діалогу культур досліджували Ю. Апресян, О.Арцишевська, О. Більєв, І.Горєлов, О. Горошкіна, І. Зимняя, О. Кубрякова, О. Лурія, Н. Нікітін, М. Пентилюк.

Про актуальність даної теми свідчить те, що нині існує низка досліджень з проблеми формування культурологічного світогляду на всіх етапах освітньої діяльності, серед яких виділяємо наступні: формування культурологічної компетентності як інноваційної парадигми сучасності (І. Бех, В. Андрущенко, І.Бех, В. Кремінь, С.Гончаренко, І.Зязюн, Н. Ничкало, В. Огнев'юк, Т. Герлянд, Л. Герганов, М. Євтух, Л. Єршова, А. Каленський, П. Лузан, М. Пантюк, Л. Пригодій, В. Орлов, І. Пасічник, Л. Пуховська, В. Радкевич, Л. Романишина, С. Сисоєва, М. Теловата, О. Щербак, В. Ягупов та ін.); наукові проблеми культурологічної підготовки студентів, що досліджуються в сучасній педагогічній науці, професійної освіти у стратегії духовно-екзистенційної боротьби за оновлення суспільства (В. Андрущенко, В. Кремінь, І. Зязюн, М. Євтух, І. Сліпухіна, Г. Токмань, О. Шапран та ін.).

І. Бех накреслив алгоритм формування духовно-екзистенційних основ особистості в системному відтворенні «від культури мислення до культури духовного переживання». У статті «Духовна особистість у контексті освітніх викликів» видатний учений І.Бех наголошує: «Багатовікове відчуження людини від справжніх духовних цінностей призвело до кризових явищ, пов'язаних із занепадом духовно-моральних ідеалів, посиленням зла і насильства. Девальвація духовних цінностей суттєво вплинула на посилення тенденції зростання жорстокого індивідуалізму, прагматизму, зверхнього ставлення до інших людей та приниження їхньої гідності, зневаги до рідної культури та історикокультурних традицій» (Бех, 2019, с. 3).

Мета статті - на основі аналізу творчості Анатолія Крима розглянути проблеми формування культурологічного мислення студентів як предмет цілісного та системного дослідження, що складає основу гуманітарної безпеки суспільства, показати вплив предметів гуманітарного циклу на формування культурологічного світогляду молодої людини, показати тенденції співпраці технічної та гуманітарної складових педагогічно зорієнтованої педагогіки сучасності.

Матеріали і методи дослідження: під час дослідження було використано компаративний, історико-логічний, синергетичний методи. Зазначений методологічний підхід дозволив проаналізувати системне творення гуманітарної безпеки суспільства як складової загальної гуманітарної парадигми сучасної інноваційної складової людино центричної педагогіки. 
Виклад основного матеріалу. Особливість творчого архетипу сучасного письменника Анатолія Крима полягає у спорідненій єдності генетичних пракоренів українського та єврейського народів, коли автор, створюючи архетипний міф сучасного інтелектуального мислення, творить закорінену філософсько-екзистенційну модель культурологічної парадигми сучасності. У творчому доробку письменника десятки повістей, романів, драм.

Анатолій Крим - «автор романів «Выбор» (1979; 1989), «Граница дождя» (1982; 1989), «В ожидании мессии» (1989; усі - Київ), «Девятый круг» (Уж., 1989), «Труба» (К., 2010); зб. оповідань «Запах сосновой смолы», повістей «Неугомонный Абрикосов» (обидві - Ужгород, 1983), «Заложники отеля “Европа"» (1985; 1991), «Чакона» (1986; усі - Київ), зб. «Рассказы о еврейском счастье» (О., 2005; К., 2008; Москва, 2009); п'єс «Долгая дорога домой» (1973, Саратов. театр драми, РФ; окреме вид. - К., 1985), «Наздожени свій поїзд» (1977, реж. В. Опанасенко), «Фиктивный брак» (1981; поставлено 1982, реж. А. Литвинчук; окреме вид. - К., 1994), «Теплый пепел» (1984, реж. К. Пивоваров), «Нелегалка» (1994, реж. О. Мосійчук; усі - Чернів. укр. муз.-драм. театр ім. О. Кобилянської), «Азбука революции» (1982), «Лифт на седьмой этаж» (1983), «Продается динозавр», «Пизанский шкаф» (обидві - 1985), «Еретик» (1986), «Евангелие от Ивана» (2003), «Завещание целомудренного бабника» (К., 2005; Москва, 2008), «Осень в Вероне, или Правдивая история Ромео и Джульетты» (К., 2007); сценаріїв «Возвращение блудного мужа», «Дни надежды», «Жажда экстрима», «Квартет для двоих» (усі - 2007), «Ой, мамочки...» (2008), «Менты. Тайны большого города» (2012)». За сценаріями Анатолія Крима знято цілий ряд художніх фільмів.

Дослідження творчості Анатолія Крима потребує усвідомлення інноваційних духовно-екзистенційних вимірів сучасності, коли найцікавіші тексти творяться як частина системної комунікації зі світом.

Художній твір на початку нового тисячоліття вже перестає відігравати суто естетичну роль. На його долю випало стати предтечею народженння нових духовних форм сучасного буття, в основі яких лежить система квантового мислення.

Дана система утворюється, коли заперечення заперечення стає основою нової архетипної моделі буття, коли ламаються старі стереотипи задля народження нових дієвих парадигм, здатних модернізувати духовні шляхи розвитку людства. Література перестає бути «штукою для штуки» вона розриває модель чисто літературного простору, вибудовуючи нову архетипну систему навколишнього світу.

За цих умов історико-географічна приналежність літературного тексту виривається за межі своєї системи, вибудовуючи нову модель яскравого світосприйняття. Перетин культур утворює енергію високої вибухової сили. у цьому горнилі народжуються інноваційні духовні форми осмислення 
духовного світу сучасного буття. Особливість даних архетипних моделей полягає в тому, що вона опадає живильними дощами на географічноісторичну ниву того соціуму, у якому вона витворена.

Сміємо стверджувати, що література, творена на українських теренах представниками інших націй, - цікаве і самобутнє явище не лише для української культури; позаяк, закорінена у власний етнос, вона стає засобом порозуміння між народами. Єврейський світ творчості Анатолія Крима, одинаково цікавий як для єврейського, так і для українського народів.

3 відходом тоталітарної системи талановитий художній текст дістав унікальну можливість стати засобом як міжчасової комунікації - у вертикальному зрізі; так і частиною географічної комунікації, засобом порозуміння між народами - у горизонтальному вимірі. Творчість Анатолія Крима творить інноваційний генетичний архетип дружби українського і єврейського народів.

Загальний аналіз видатних культурологічних явищ сучасності переконливо доводить, що в системному діалогові культур відбувається питоме переміщення інтелектуального дійства сучасного буття. Достатньо поглянути на архетипну модель лауреатів Нобелівської премії останніх років.

Тематичний аналіз їхніх досягнень заглиблення у внутрішній світ людської індивідуальності, намагання переформатувати гносеологічність поглядів людства у світ ірреальних площин. Не закривати очі на пекучі болячки дійсності, а змусити силою своєї мислительної діяльності примусити людство силою думки змінити траєкторію польоту від матеріально-духовної площини до духовно-матеріальної.

Знайти третю точку опори для людства, коли вихід за межі власного «я» диктує необхідність повернення до площинної рівноваги. Про що $б$ не писали видатні письменники сучасної епохи, вони пишуть історію повернення людства до своїх праоснов. Найбільш чуттєвою і вразливою цариною для такого виду інтелектуального дійства виступає література інноваційної інтелектуальної епохи, представником якої $€$ видатний письменник сучасності Анатолій Крим.

Архетипні корені його літературних одкровень, явлені світові російською мовою, споріднені з поетичними дороговказами класиків світової літератури. Відлуння архетипних коренів українського світобачення та генетичного єврейського проникнення вплітаються в колористичну соковиту барву текстів, витворюючи шляхетне літературне дійство.

Питання перебігу єврейсько-українського культурного діалогу i сьогодні викликає чимало дискусій в інтелектуальних колах України та світу. Щодо його літературної складової, то фрагментарність представлення творчості сучасних світових авторів українському читачеві, а також комерційний фактор впливу на представлення того чи іншого твору складають типову ситуацію. Аналіз філософсько-психологічної основи 
естетичного коду творчості Анатолія Крима переконливо доводить, що дві культури перебувають у постійному творчому діалозі. У духовному взаємопроникненні й використанні їх творчості у змісті професійної освіти буде вагомою основою для формування культури міжнаціонального спілкування у студентському середовищі.

Сьогодні українська література перебуває в процесі становлення та переутвердження свого місця серед світових літератур. Інтерес зарубіжного літературознавства до української літератури невпинно зростає.

Аналогічну картину ми спостерігаємо в архетипі письменницьких одкровень Кадзуо Ісіґуро, творчість якого сучасні дослідники порівнюють із творчістю Джозефа Конрада та Володимира Набокова, які творили унікальні твори мовою іншого генетичного архетипу. Але, на наш погляд, якраз діалог різних культур, закладений у парадигмальному творчому зрізі даних авторів, дозволяє митцям ступити на якісно вищий рівень творчого одкровення, яке споріднено суголосне із квантовим мисленням новітньої епохи.

у творах духовного одкровення допомагає перейти безодню розхристаного світу. Зв'язок людського індивідуальності та навколишнього світу дозволяє перейти від ілюзорного споглядання до ірраціонального осмисленого взаємопроникнення. Рятуючи світ ти рятуєш себе та рятуючи свою душу від нищення. Ти простягаєш руку допомоги світові. Такий духовний імператив характерний для найбільш знакових творів сучасності.

На зламі тисячоліть література як вид мистецтва повертається до своїх основ, вбираючи в себе невидимі потоку духовної енергії світу. Вона стає лакмусовим папірцем, який допомагає людству усвідомити справжність свого існування. Знаки-символи, відображені у кращих художніх творах сучасності, вбирають у себе хаос навколишнього буття, переплавляючи його в золоту енергію думки. Література стає виразником найпрогресивніших духовних сентенцій сучасності, стаючи основою для творення архетипу моделі сучасного інноваційного мислення.

Світлана Аліксієвич - виразник моделі більш рапціональнопрагматичної ніші сучасного квантового мислення. Вона до найменших деталей розкладає на атоми стигми минулого буття. Секонд-хенд обпаленого вогнем парадигми мистецького світу Світлани Аліксієвич має унікальний всеохопний зміст руйнування духовних імперій сучасності. Яку ціну готове заплатити людство за своє бажання не виживати, а вижити? Один раз і назавжди відрізати гнійні болячки старих цивізаційних систем.

Образ війни у творчості Світлани Аліксієвич має всеохопно-узагальнювальний смисл: це війна людства за своє виживання. Архетипний смисл «жіночої» моделі за духовно-екзистенційну перебудову світу - це повернення до пракоренів людства, коли жертовність поразки стає перемогою.

Даний архетип новітньої культурологічної епохи яскраво відчитується в художніх текстах Анатолія Крима. Про такий символізм у творчості Тараса 
Шевченка писав видатний критик нашої сучасності Григорій Грабович, коли жіноче архетипне начало Шевченка ставало гімном супротиву людства проти бездуховності, яка веде не просто до занепаду, а до згортання тривання людських цивілізацій. Мойсеєвим ходом у пустелі можна назвати драму Анатолія Крима «Нелегалка», що успішно пройшла на сценах багатьох театрів.

Здатність любити - це найбільше благо. І власне за цією здатністю йде глибока прірва між персонажами п'єси Анатолія Крима «Нелегалка»; між тими, які навчилися пристосовуватися і хочуть видаватися в очах оточуючих особливо «правильними», господарями життя й тими, які беззастережно ідуть за своїм почуттям і відстоюють своє право на щастя. Між нами - вічний конфлікт, як одвічний конфлікт між циніками і романтиками, між лицарями і бандитами.

Жіночий образ у п'єсі Анатолія Крима, попри свою конкретну заглибленість у сучасність, набуває смислового узагальненого значення. Він $\epsilon$, одночасно, і причиною конфлікту, і самим конфліктом, і фантомом доби. Письменник сміється - крізь сльози розпачу, перечулення, щастя, надії... Сміється так, як може сміятися нація, яка навчилася йти до свого щастя через геноциди, голодомори, концтабори, тюрми... яка навчилася мудрості й витривалості, яка навчилася перемагати - через біль і розчарування. Та навіть у тому сміхові відчувається скрип піску на зубах Мойсеєвої пустелі.

На основі вивчення культурологічних набутків сучасності можна сказати, що важливою умовою формування сучасного спеціаліста $\epsilon$ культура, що проявляється в умінні вирішувати проблеми в умовах складності завдань. Поняття «проектна культура» стає все більш актуальною в сучасній професійній освіті. Успішність якісної підготовки фахівців залежить від становлення проектної культури особистості в процесі освіти як важливої частини загальної й професійної культури.

Визначення впливу людського потенціалу, зокрема інтелектуальної складової на розвиток держави в умовах глобалізації та окреслення проблем, з якими стикається держава при впровадженні інноваційних моделей, потребує якісного використання всіх накопичених культурологічних здобутків. У тому числі і в сучасній літературі. Як бачимо з вищенаведеного, потенційно інтелектуальним потенціалом володіє кожна країна, однак оптимально навчитись його використовувати - завдання сучасної філософії, естетики, культурології. Ці суспільні процеси не можуть не знаходити свого віддзеркалення в літературі інтелектуального напрямку, для якої важлива не лише констатація фактів, а й пошуки нових шляхів розвитку науки (у тому числі і педагогічної) та суспільства.

Висновки та перспективи дослідження. На прикладі синергетичного дослідження духовно-екзистенційних коренів творчості сучасного 
письменника Анатолія Крима розглядаються архетипи творення духовноекзистенційних вимірів сучасності, коли найцікавіші літературні тексти творяться як частина системної комунікації зі світом. У дослідженні доводиться, що художній твір на початку нового тисячоліття вже перестає відігравати чисто естетичну роль.

Осмислення розвитку культурологічної складової в системі формування культурологічної компетентності сучасного студента дає інноваційний початок наближення соціуму до загальнолюдських цінностей, що є основою гуманітарної безпеки суспільства. У дослідженні показано, як системне порозуміння між народами $\epsilon$ творчою вимогою зображення дійсності у творчості Анатолія Крима. Даний художньоестетичний вимір стосується глибини й істинності узагальнень, культурологічної цінності художньої творчості письменника в цілому.

На прикладі вивчення творчості сучасного письменника Анатолія Крима розширюються уявлення про синергетичну взаємодію між формуванням світогляду людини та гармонійним розвитком соціального буття, що становить основу творення духовної свободи особистості. У дослідженні доводиться, що художній твір на початку нового тисячоліття вже перестає відігравати чисто естетичну роль, на його долю випало стати предтечею народження нових духовних форм сучасного буття. Позаяк дискурс літературного тексту в системі культурологічного осмислення сучасності в часо-просторовому вимірі створює архетипну модель культурологічної парадигми сучасності.

На прикладі аналізу творчості Анатолія Крима бачимо, що культурологічна парадигма сучасності найважливішою своєю складовою має формування культурологічного світогляду, уміння бачити причиннонаслідкові механізми явищ навколишньої дійсності.

\section{ЛITEPATУPA}

Базиль, Л. О. (2004). Становлення і розвиток літературної освіти в Україні у 19181938 рр. (дис. ... канд. пед. наук). K. (Basil, L. O. (2004). Formation and development of literary education in Ukraine in 1918-1938 (PhD thesis). K.).

Бальзак, О. (1981). Думки про мистецтво. К.: Мистецтво (Balzak, О. (1981). Thougts about the Art. K.: Art).

Бех, І. Д. (2019). «Духовна особистість у контексті освітніх викликів». Рідна школа, 1, 3-7 (Bekh, I. D. (2019). "Spiritual personality in the context of educational challenges". Native School, 1, 3-7).

Кремень, В. Г., Ткаченко, В. (1999). Україна: Шлях до себе. Проблеми суспільної mрансформації. К. (Kremen, V. H., Tkachenko, V. (1999). Ukraine: The way to oneself. Problems of social transformation. K.).

Кремень, В. Г. (1989). Філософія національної ідеї. Людина. Освіта. К. (Kremin, V. Н. (1989). Philosophy of the national idea. Man. Education. K.).

Крим, А. (1989). Граница дождя. К. (Krym, А. (1989). The border of the rain. K.).

Крим, А. (2005). Рассказы о еврейском счастье. Одеса (Krym, A. (2005). Stories about the Jewish happiness. Odesa). 
Мистецтво у розвитку особистості (2006). Чернівці: Зелена Буковина (Art in the person's development (2006). Chernivtsi: Zelena Bukovina).

Теліга, Олена (1977). Збірник. Редакція і примітки О. Ждановича. Детройт-Нью-ЙоркПариж (Teliga, Olena (1977). Collection. Editorial and notes by O. Zhdanovych. Detroit-New York-Paris).

Токмань, Г. Л. (2012). Методика навчання української літератури в середній школі. К.: Академія (Tokman, H. L. (2012). Methods of teaching Ukrainian literature in secondary school. K.: Academy).

\section{PEЗЮME}

Якубовская Мария. Духовно-экзистенциальный архетип коммуникативного диалога писателя Анатолия Крыма как средство формирования культурологической компетентности.

На примере исследования творчества выдающегося современного писателя Анатолия Крыма рассматриваются проблемы формирования культурологической компетентности современного студента как основы создания новой культурологической парадигмы современности, что является важным фактором формирования гуманитарной безопасности общества. Методология исследования заключается в применении сравнительного, историко-логического, синергетического методов. Исследуется системное создание культурологической модели художественного текста как целостного функционального единства сущности художественного слова и окружающего мира, расширяется представление о синенергетичном взаимодействии между формированием мировоззрения человека и гармоничным развитием социума.

Ключевые слова: культурологчческая компетентность, культурологчческое мировоззрение, дискурс, синергия слова, философско-психологический код слова, искусство общения, культурологическая среда, архетип произведения.

\section{SUMMARY}

Yakubovska Marila. Spiritual-existent archetype of the communicative dialogue of the writer Anatolii Krym as a means of cultural competence of a modern student.

On the example of the study of creativity of the prominent contemporary writer Anatolii Krym, the problems of forming the cultural competence of the modern student are considered as the basis for the creation of a new cultural paradigm of the present, which is an important factor in shaping humanitarian security of society. The role of the artistic text in the philosophical and existential reproduction of the model of the epoch of the beginning of the 21st century is analyzed, the archetype of creation of the philosophical and psychological code of the word is investigated. The methodology of the study is to apply comparative, historical-logical, synergistic methods. This methodological approach allows us to analyze the systematic creation of the cultural model of the artistic text as a complete functional unity of the essence of the artistic word and the world around it.

The scientific novelty of the work is to broaden the concept of synergetic interaction between the formation of the world outlook of the person and harmonious development of social being, which is the basis for the creation of spiritual freedom of the individual. Comparative analysis of development of literature as the art of words provides an opportunity to understand more deeply, on the example of understanding between the Ukrainian and Jewish peoples, the cultural component of the universal cultural paradigm of our time. 
Conclusions and prospects of the study. The example of a synergetic study of the spiritual-existential roots of the work of a contemporary writer Anatolii Krym examines the archetypes of creation of spiritual-existential dimensions of modernity, when the most interesting literary texts are created as part of systemic communication with the world. The study argues that the work of art at the beginning of the new millennium has ceased to play a purely aesthetic role.

Understanding development of the cultural component in the system of forming the cultural competence of the modern student gives an innovative start to the approach of society to human values, which is the basis of humanitarian security of society.

Key words cultural competence, cultural outlook, discourse, synergy of words, philosophical and psychological code of words, art of communication, cultural environment, archetype of a work. 